PSYCHOLOGIA ROZWOJOWA, $2017 *$ tom 22 , nr 1, s. $47-58$

doi:10.4467/20843879PR.17.003.6417

www.ejournals.eu/Psychologia-Rozwojowa

OLGA BĄK

Instytut Psychologii, Uniwersytet Wrocławski

Institute of Psychology, Wroclaw University

e-mail: olga.bak@uwr.edu.pl

\title{
Styl wychowania a informacje zwrotne w komunikacji rodziców $\mathrm{z}$ adolescentami
}

\section{Parenting Style and Feedback in Communication between Parents and Adolescents}

\begin{abstract}
The article presents the results of research related to feedback from parents with various parenting styles, divided according to Diana Baumrind's conception into authoritative, authoritarian or permissive. The aim of the study was to determine what kind of positive and negative feedback is characteristic of each style. The study was conducted among adolescents, aged 16-19, $\mathrm{N}=226$. Both the parenting styles and feedback were studied from the adolescent's perspective. The following methods were applied: Parental Authority Questionnaire (Buri, 1991) and our own method: Questionnaire of Feedback in Parent-Child Relations. The results show that the most significant correlations occurred between feedback and the authoritative style. The stronger the authoritative style of the parent was (both for mothers and fathers), the more often the adolescent experienced positive feedback (general, specific and trait-related) and constructive criticism from the parent, and the less often there was a lack of reaction from the parent. The authoritarian parenting style was connected with less effective communication, in which negative feedback predominated. There was no clear pattern between feedback and the permissive style.
\end{abstract}

Keywords: parenting style, feedback.

Słowa kluczowe: styl wychowania, informacje zwrotne.

\section{WPROWADZENIE}

Styl wychowania w rodzinie jest kategorią opisującą względnie stały sposób zachowywania się rodziców wobec dziecka. W latach 60. XX wieku Diana Baumrind $(1966,1967)$ opisała trzy niezależne wzorce oddziaływań rodziców, które odpowiadają za proces socjalizacji dzieci: styl autorytatywny, autorytarny oraz permisywny. Styl autorytatywny cechuje się okazywaniem dziecku pozytywnych uczuć i akceptacji, reguły formułowane przez rodziców są bardzo wyraźne i stałe, wymagania wysokie, ale adekwatne do możliwości dziecka i sprzyjające rozwojowi, komunikacja ma charakter wzajemny, rodzice respektują opinie dziecka. Styl autorytarny jest natomiast wysoce dyrektywny, wymagający bezwzględnego posłuszeństwa, rodzice okazują niewiele uczuć, komunikacja ma charakter jednostronny (dziecko ma obowiązek bezdyskusyjnie przyjąć to, czego rodzic wymaga), kontrola zachowania odbywa się głównie przez metody punitywne. Rodzice permisywni mają z kolei akceptujący stosunek do dziecka, formułują jednak mało wymagań wobec niego, nie kontrolują dziecka, lecz pozwalają, aby samo decydowało, co i jak chce robić i minimalizują kary. Konsultują z dzieckiem swoje decyzje i wyjaśniają zasady obowiązujące $\mathrm{w}$ rodzinie. 
Ten krótki opis stylów wychowania pokazuje, że najważniejsze są w nich cztery aspekty: stosunek emocjonalny do dziecka, stałość i jasność wyrażania reguł, formułowanie wymagań wobec dziecka oraz komunikacja. Niestety, ostatni z tych aspektów opisywany jest jedynie w bardzo ogólnikowy sposób przez koncentrację na tym, czy komunikacja ma charakter wzajemny (verbal give-and-take), czy jednostronny oraz czy wyraża pozytywny stosunek do dziecka.

Szersze zbadanie tego, jak wygląda komunikacja w obrębie każdego stylu, wydaje się istotnym poszerzeniem obrazu relacji między rodzicami a dzieckiem. Komunikacja interpersonalna nie dotyczy bowiem jedynie bieżącej wymiany informacji między nadawcą a odbiorcą, ale definiuje również relację między nimi, ujawniając wzajemne ustosunkowania. Ponadto komunikacja w rodzinie stanowi wzór dla późniejszych relacji między dzieckiem a osobami spoza rodziny oraz we własnej rodzinie w dorosłości (Harwas-Napierała, 2006).

Zagadnienie komunikacji między rodzicem a dzieckiem jest także istotne $\mathrm{z}$ punktu widzenia psychologii rozwoju człowieka. Przede wszystkim, odnosząc się do ogólnych teorii rozwoju, ujmujących go jako gromadzenie doświadczeń (por. Tyszkowa, Przetacznik-Gierowska, 1996; Liberska, 2011), można zauważyć, że komunikacja rodzinna umożliwia kumulowanie zarówno doświadczeń społecznych (gdy wiąże się z przekazywaniem treści dotyczących kultury, zwyczajów, postaw itp.), jak i doświadczeń indywidualnych (np. gdy otoczenie rodzinne przez swoje komunikaty wpływa korygująco na zachowanie człowieka). Ponieważ w rodzinie ,nie można się nie komunikować” (nawet brak reakcji werbalnej ma swoją wartość informacyjną; por. Watzlawick, Beavin, Jackson, 1967, za: Harwas-Napierała, 2006), komunikacja $\mathrm{z}$ innymi jest zatem jednym $\mathrm{z}$ głównych narzędzi zdobywania doświadczenia. Ponadto jeśli rozwój odbywa się dzięki interakcji czterech grup czynników: zadatków biologicznych, środowiska, wychowania i aktywności własnej podmiotu, to komunikacja jest procesem integrującym zwłaszcza te dwa ostatnie (Brzezińska, 2000). Nawet spontanicznie podjęta aktywność podmiotu może być przez komunikaty słowne otoczenia (rodziców) stymulowana, ukierunkowywana lub powstrzymywana (np. zgodnie z wizją wychowania prezentowaną przez rodziców), przyczyniając się do rozwoju indywidualnego, który będzie przebiegał w określonym tempie i kierunku.

Warto też zaznaczyć, że sam proces komunikacji w rodzinie podlega rozwojowym przekształceniom, wynikającym z normatywnego indywidualnego rozwoju partnerów interakcji (Harwas-Napierała, 2006). Komunikacja w początkowych okresach rozwojowych jest wyraźnie asymetryczna (chociaż wzajemna), z dominującą rolą rodziców, a od okresu adolescencji powinna ewoluować w kierunku zwiększania symetrii komunikacyjnej między rodzicem a dzieckiem. Zwłaszcza pojawiające się $\mathrm{u}$ adolescentów potrzeby samodzielności i autonomii wymuszają zmiany wzorców komunikacyjnych.

W niniejszej pracy szczególna uwaga została skierowana na pewien rodzaj komunikatów, które są przekazywane w ramach każdej interakcji - na informacje zwrotne (feedback). W klasycznym podstawowym ujęciu feedback to informacja mówiąca o tym, czy zachowanie podmiotu było właściwe (Barbour, 2003; Bee, Bee, 2000; Stone, Heen, 2014). Tę definicję można poszerzyć, odnosząc ją nie tylko do zachowań, lecz także do różnych aspektów funkcjonowania człowieka, które komentują obserwatorzy (uczestnicy interakcji). Informacje zwrotne będą zatem traktowane w niniejszej pracy jako rodzaj werbalnej (lub niewerbalnej) reakcji na to, co człowiek zrobił, powiedział, jak wygląda lub jakie są rezultaty jego działania.

Głównym celem informacji zwrotnych w komunikacji jest wpływanie na obserwowane zachowanie (mimikę, wygląd, wypowiedź, konsekwencje działania), aby utrzymać na dotychczasowym poziomie lub wzmocnić to, co pożądane, bądź zmodyfikować, poprawić to, co wymaga zmiany (Barbour, 2003). Zdaniem wielu badaczy informacje te są nie do przecenienia w wychowaniu, uczeniu się i rozwoju na różnych etapach życia (por. np. Kamins, Dweck, 1999; Hattie, Timperly, 2007; Gunderson, Gripshover, Romero, Dweck, Goldin-Meadow, Levine, 2013). 
Oprócz podstawowej funkcji, polegającej na wpływaniu na zachowanie, informacje zwrotne mogą też pełnić funkcje dodatkowe, istotne dla samej relacji: wyrażają zainteresowanie wobec tego, co dziecko robi, służą podtrzymaniu relacji (np. potakiwanie głową jest zarówno sygnałem: ,zgadzam się", jak i informacją: ,ja cię słucham”), mogą wyrażać wsparcie (,,ale jesteś mądry!"), a niekiedy służą odreagowaniu emocji (np. dezaprobujący okrzyk: „,o ty robisz?!”).

Informacje zwrotne rozpatruje się zwykle z uwzględnieniem przynajmniej dwóch kryteriów: wartościowości oraz sposobu sformułowania. Pierwsze uwzględnia znaczącą rolę informacji zwrotnych w modyfikowaniu zachowania. Zgodnie z nim wyróżnia się informacje pozytywne i negatywne (Bee, Bee, 2000; Barbour, 2003). Informacje pozytywne (potocznie nazywane pochwałami) aprobują zachowania i/lub jego efekty, wskazują, że można je kontynuować, gdyż jest właściwe i przynosi pożądane rezultaty. Informacje negatywne z kolei są wyrazem krytyki, dezaprobują zachowania i/lub jego konsekwencję. Nadawca takiego komunikatu sygnalizuje, że zachowanie lub jego rezultaty powinny zostać ograniczone lub zmienione.

Drugie kryterium uwzględnianie w analizach definicyjnych odnosi się do sposobu sformułowania informacji zwrotnej (zarówno pozytywnej, jak i negatywnej). Informacje zwrotne mogą być przekazane w sposób efektywny (konstruktywny) lub nieefektywny (a czasem nawet destrukcyjny). Najbardziej efektywne, pożądane przez odbiorców i mające największy wpływ na późniejsze zachowanie okazują się informacje szczegółowe. Zawierają one precyzyjną informację, co jest właściwe lub niewłaściwe w zachowaniu i - w tym drugim wypadku - jak można je poprawić. Otrzymanie takiej informacji pozwala w przyszłości powtarzać lub intensyfikować zachowania właściwe i korygować niepożądane (konstruktywna krytyka).

W codziennej komunikacji interpersonalnej pojawiają się też informacje zwrotne, które charakteryzują się zdecydowanie niższą efektywnością, są to ogólne informacje oceniające, informacje etykietujące, generalizacje oraz krytyka wyrażona w sposób niewłaściwy (destrukcyjna). Ogólne informacje oceniające (np.: „,pięknie!”, „beznadziejnie!”), chociaż wyrażają aprobatę lub dezaprobatę zachowania, nie zawierają podpowiedzi, co jest szczególnie cenne lub naganne $w$ zachowaniu, więc odbiorca może tylko odczytać z komunikatu nastawienie do jego zachowania, ale wnioski odnośnie do dalszego postępowania musi wyprowadzać samodzielnie. Informacje w postaci etykiet, epitetów i odwołań do cech (np.: ,jesteś leniwy", ,jesteś inteligentny") skłaniają z kolei odbiorcę do postrzegania siebie w kategoriach niezmiennych właściwości, które trudno jest kontrolować, co może skutkować utrzymywaniem się zachowań niepożądanych lub wycofywaniem wysiłku w sytuacji, kiedy weryfikowane mogą być pozytywne cechy (Kamins, Dweck, 1999). Informacje w postaci generalizacji (np.: ,jak zawsze zrobiłeś to bardzo ładnie”; ,nigdy nie można na ciebie liczyć") wyrażają aprobatę lub dezaprobatę przez użycie kwantyfikatora wskazującego na większy zakres danego zachowania. Odbiorca takiej informacji odczytuje z nich, jaki jest stosunek nadawcy do tego zachowania, ale prawdopodobnie nie ma przekonania, że konkretne zachowanie ma znaczenie. W komunikacji zwrotnej zdarza się również taka krytyka, która jest informacją deprecjonującą, nieprzychylną, destrukcyjną (np. ,,robisz to bezmyślnie!”), z której odbiorca odczytuje negatywny stosunek do siebie i/lub zachowania, bez wskazówek, co mógłby poprawić w przyszłości.

Wymienione powyżej formy informacji zwrotnych efektywnych i nieefektywnych nie stanowią systematycznej typologii, lecz są przykładami komunikatów, które pojawiają się w codziennych interakcjach. Warto zaznaczyć, że badacze problematyki informacji zwrotnych (w obszarze wychowania i edukacji) wprowadzają też inne podziały informacji zwrotnych, z uwzględnieniem ich treści i efektywności. Przykładowo Melissa Kamins i Carol Dweck (1999) koncentrują się na informacjach zwrotnych odnoszących się do osoby (person feedback), do wyniku (outcome) oraz do sposobu wykonywania zadania (process) i zdecydowanie większą efektywność przypisują tym ostatnim. Podobnie John Hattie i Helen Timperly (2007) wyróżniają informacje zwrotne mające związek ze sposobem wykonywania (process 
feedback), zadaniem (task feedback), dotyczące własnych procesów regulacyjnych zaangażowanych w wykonywanie zadania (feedback about self-regulation) oraz informacje zwrotne odnoszące się do ,ja" (person feedback). Największą efektywność przypisują informacjom o sposobie wykonywania zadania oraz odnoszącym się do procesów samoregulacyjnych, a najmniejsze znaczenie dostrzegają w informacjach odnoszących się do cech osoby.

\section{CEL BADANIA I HIPOTEZY}

Chociaż informacje zwrotne stanowią ważny aspekt komunikacji, gdyż mogą ukierunkowywać działania podmiotu, do tej pory nie rozpatrywano ich jako elementu stylu wychowania. W związku z tym, głównym celem tego artykułu jest ustalenie, jakie informacje zwrotne są charakterystyczne dla poszczególnych stylów wychowania prezentowanych przez matki i ojców. Biorąc pod uwagę właściwości danych stylów, można sformułować następujące hipotezy:

1. Im większe nasilenie stylu autorytatywnego, tym częściej dziecko otrzymuje od rodziców pozytywne informacje zwrotne, zwłaszcza w postaci szczegółowych i ogólnych wyrazów aprobaty. Ponieważ komunikacja w tym stylu wydaje się najbardziej otwarta na dyskusję i wymianę opinii (partnerska), charakterystyczne dla niego będzie również częstsze stosowanie konstruktywnej krytyki, która jest metodą efektywnego korygowania zachowań niepożądanych.

2. Im większe nasilenie stylu autorytarnego, tym rzadziej rodzice będą formułować pozytywne informacje zwrotne, a częściej pojawią się nieefektywne komunikaty negatywne (destrukcyjna krytyka, informacja etykietująca i generalizacja).

3. Im większe nasilenie stylu permisywnego, tym częściej rodzice będą powstrzymywać się od informacji zwrotnych zarówno pozytywnych, jak i negatywnych.

\section{METODY}

Aby zweryfikować powyższe hipotezy zastosowano dwie metody kwestionariuszowe. Pierwszą jest Kwestionariusz Autorytetu Rodzicielskiego (Parental Authority Questionaire, PAQ), którego autorem jest John Buri (1991). Narzędzie to pozwala na zbadanie stylu wychowania $\mathrm{w}$ rodzinie: autorytatywnego, autorytarnego oraz permisywnego (zgodnie z koncepcją D. Baumrind), ocenianego z perspektywy dziecka w okresie starszej adolescencji i wczesnej dorosłości. Kwestionariusz występuje w wersji dotyczącej stylu wychowania matki oraz stylu wychowania ojca (dwa odrębne arkusze, identyczne pod względem treści). Składa się z 30 twierdzeń (po 10 dla każdego stylu), dobranych przez sędziów kompetentnych na podstawie analizy treściowej i zgodności pozycji z definicją danego stylu. Do każdego twierdzenia osoba badana ustosunkowuje się na 5-punktowej skali Likerta, gdzie 1 oznacza „zdecydowanie nie zgadzam się", a 5 - ,zdecydowanie zgadzam się". Dla każdego stylu wychowania oblicza się wynik sumaryczny, mieszczący się w przedziale od 10 do 50. Im wyższy wynik, tym bardziej rodzic w swoich relacjach z dzieckiem prezentuje cechy charakterystyczne dla danego stylu (czyli jest to wskaźnik nasilenia danego stylu). Dla każdego rodzica oblicza się jednocześnie trzy wskaźniki - odpowiadające trzem stylom. Na podstawie wyników nie przesądza się, który styl wychowania dominuje. Jest to wyraźna różnica $\mathrm{w}$ stosunku do oryginalnej koncepcji D. Baumrind, według której style są niezależne od siebie i rodzic prezentuje tylko jeden $\mathrm{z}$ nich.

J. Buri (1991) ustalił parametry psychometryczne metody w zakresie trafności i rzetelności (stabilność i zgodność wewnętrzną). Okazały się one satysfakcjonujące. Metoda jest powszechnie stosowana w badaniach naukowych ${ }^{1}$.

W tabeli 1 zawarto współczynniki zgodności alfa Cronbacha dla grupy uczestniczącej w niniejszym badaniu oraz - dla porównania - wskaźniki dla wersji oryginalnej. Dla stylów autorytatywnego i autorytarnego zgodność jest wysoka, wyraźnie niższa, aczkolwiek satysfakcjonująca, jest natomiast dla stylu permisywne- 
Tabela 1. Współczynniki zgodności wewnętrznej alfa Cronbacha dla wersji oryginalnej PAQ i wersji polskiej

\begin{tabular}{|l|c|c|}
\hline \multicolumn{1}{|c|}{ Skala PAQ } & $\begin{array}{c}\text { Wersja oryginalna* } \\
\mathbf{N = 1 8 5}\end{array}$ & $\begin{array}{c}\text { Wersja polska - dane } \mathbf{z} \text { bieżą- } \\
\text { cego badania }\end{array}$ \\
\hline Styl autorytatywny - matka & .82 & .81 \\
\hline Styl autorytarny - matka & .85 & .76 \\
\hline Styl permisywny - matka & .75 & .54 \\
\hline Styl autorytatywny - ojciec & .85 & .86 \\
\hline Styl autorytarny - ojciec & .87 & .80 \\
\hline Styl permisywny - ojciec & .74 & .70 \\
\hline
\end{tabular}

Źródło: * Buri, 1991.

go. Warto zauważyć, że również w wersji oryginalnej pytania dotyczące stylu permisywnego charakteryzują się najniższą spójnością.

Drugim narzędziem zastosowanym w badaniu był autorski Kwestionariusz Informacji Zwrotnych w Relacjach Rodzice-Dziecko (przygotowany przez zespół: Olga Bąk, Magdalena Trzebińska, Marta Rawa; por. Rawa, 2012), służący do badania częstości pojawiania się w komunikacji werbalnej różnych form informacji zwrotnych, prezentowanych przez rodziców. Kwestionariusz składa się z 12 krótkich opisów sytuacji: 6 dotyczy codziennych sytuacji wychowawczych (zachowania dziecka w domu, wobec innych osób, wypełniania obowiązków domowych, wykonywania poleceń, posłuszeństwa wobec rodziców), a 6 odnosi się do sytuacji edukacyjnych (związanych ze szkołą i nauką). Połowa sytuacji opisuje zachowania pozytywne, a połowa negatywne. Do każdej sytuacji podano 5 możliwych werbalnych informacji zwrotnych rodzica. Reakcje te są zróżnicowane ze względu na sposób sformułowania bardziej lub mniej efektywny/konstruktywny.

Do zachowań pozytywnych przypisano 5 następujących typów pozytywnych informacji zwrotnych:

1. informacja pozytywna szczegółowa - najbardziej efektywna pochwała zachowania, wskazująca konkretne walory zachowania, np. „Dzięki temu, że rozwijasz swoje za- interesowania, byłeś w stanie mi pomóc. Bardzo mi się to podoba";

2. informacja pozytywna ogólna - wyraz aprobaty zachowania, zawierający ogólną ocenę, np.: ,świetnie”, „,bardzo ładnie”; jest to informacja cechująca się mniejszą efektywnością niż informacja szczegółowa;

3. pozytywna etykieta - wyrażenie aprobaty przez odwołanie się do cech dziecka lub użycie etykietującego określenia, np.: ,jesteś pracusiem", ,,jesteś ambitny"; taki rodzaj pochwały charakteryzuje się niską efektywnością (por. Kamins, Dweck, 1999);

4. pozytywna generalizacja - wyrażenie aprobaty przez użycie kwantyfikatora wskazującego na większy zakres danego zachowania, np. ,jak zawsze bardzo dobrze się spisałeś"; jest to również informacja o niskiej efektywności;

5. brak reakcji na zachowania pozytywne.

Do zachowań negatywnych przyporządkowano 5 następujących rodzajów negatywnych informacji zwrotnych:

1. konstruktywna krytyka - jest to informacja wskazująca, co w zachowaniu jest niewłaściwe oraz jakie to ma konsekwencje, lub pokazująca, jakie są oczekiwania dotyczące zmiany zachowania w przyszłości, np.: „Martwi mnie to, że zrezygnowałeś z dodatkowych lekcji. Nie podoba mi się to, bo do tej pory włożyłeś w nie dużo pracy. 
Powiedz mi, dlaczego podjąłeś taką decyzję, może o tym jeszcze podyskutujemy"; taki sposób sformułowania krytyki jest najbardziej efektywny (konstruktywny) ${ }^{2}$;

2. negatywna etykieta - wyrażenie dezaprobaty przez odwołanie się do cech dziecka, lub użycie etykietującego określenia, np.: „Jesteś bezczelny”, „Orłem nie jesteś”; jest to komunikat nieefektywny/destrukcyjny;

3. negatywna generalizacja - wyrażenie dezaprobaty przez użycie kwantyfikatora wskazującego na większy zakres danego zachowania, np.: „Jak zwykle niczego się nie nauczyłeś”, ,Zawsze są z tobą jakieś problemy!"; jest to komunikat sformułowany w nieefektywny sposób;

4. destrukcyjna krytyka-użycie oceniających, ogólnikowych lub poniżających określeń odnoszących się do osoby lub zachowania, z których odbiorca może odczytać negatywny stosunek do swojego postępowania, ale nie wie, jak zachowanie poprawić, np.: „Gadasz głupoty”, „No tak, czego można by się spodziewać po tobie!";

5. brak reakcji na zachowania negatywne.

Zadaniem osoby badanej (dziecka) jest wskazanie, jak często doświadcza ze strony rodziców (oddzielnie od matki i ojca) każdej $\mathrm{z}$ tych reakcji. Oceny dokonuje się na skali 5-stopniowej, gdzie 1 oznacza „nigdy”, a 5 „bardzo często”.
Przykładową pozycję z kwestionariusza (zachowanie negatywne) przedstawiono $w$ tabeli 2 . W ostatniej kolumnie zamieszczono klucz do oceny poszczególnych odpowiedzi, który w badaniu nie był prezentowany respondentom.

Dla każdego rodzaju informacji zwrotnej można obliczyć wskaźnik częstości występowania, który przyjmuje wartość od 6 do 30 (jest to suma wyników z sześciu pozycji kwestionariusza odnoszących się do danego rodzaju informacji zwrotnej).

Osoba badana informowana jest, że przedstawione sytuacje i reakcje są pewnym przybliżeniem (modyfikacją) do występujących w rzeczywistości - tzn. być może jej rodzice nie używają dokładnie takich samych sformułowań, lecz podobnych (np. jeśli w kwestionariuszu pojawia się wypowiedź: ,ale jesteś ambitny", może to oznaczać, że rodzice mówią albo dokładnie tak, albo używają innych pozytywnych określeń typu: ,jesteś pracowity”, „bystry”; ta sama zasada dotyczy wypowiedzi negatywnych).

\section{OSOBY BADANE}

W badaniu wzięli udział uczniowie szkół ponadgimnazjalnych z kilku szkół na Dolnym Ślą$\mathrm{sku}^{3}$. Do analiz włączono dane pochodzące od 226 osób (w tym: 207 wychowywanych przez oboje rodziców, 18 tylko przez matkę i 1 tylko

Tabela 2. Przykładowa pozycja z kwestionariusza

\begin{tabular}{|l|l|l|l|}
\hline \multicolumn{2}{|l|}{ Jak często Twoi rodzice reagują w następujący sposób: } \\
\hline $\begin{array}{l}\text { Gdy obraźliwie wyrażasz się o bliskich, np. ro- } \\
\text { dzeństwie, jak często Twoi rodzice tak reagują: }\end{array}$ & $\begin{array}{c}\text { Reakcja } \\
\text { matki }\end{array}$ & $\begin{array}{c}\text { Reakcja } \\
\text { ojca }\end{array}$ & KLUCZ \\
\hline „Ty zawsze tylko potrafisz obrażać innych!” & $1-2-3-4-5$ & $1-2-3-4-5$ & Generalizacja \\
\hline Nic nie mówią. & $1-2-3-4-5$ & $1-2-3-4-5$ & Brak reakcji \\
\hline $\begin{array}{l}\text { „Martwi mnie, że tak się wyrażasz o bliskich. Two- } \\
\text { je zachowanie jest niewłaściwe, ponieważ ranisz } \\
\text { innych takim postępowaniem. Może porozmawia- } \\
\text { my o tym, co skłoniło cię do takiej opinii”. }\end{array}$ & $1-2-3-4-5$ & $1-2-3-4-5$ & $\begin{array}{l}\text { Konstruktyw- } \\
\text { na krytyka }\end{array}$ \\
\hline $\begin{array}{l}\text { „Gadasz głupoty”. } \\
\text { „Jesteś bezczelny”. }\end{array}$ & $1-2-3-4-5$ & $1-2-3-4-5$ & $\begin{array}{l}\text { Destrukcyjna } \\
\text { krytyka }\end{array}$ \\
\hline
\end{tabular}


przez ojca) $\mathrm{w}$ wieku 16-19 lat (średnia $=17.5$; $S D=.8)$. W badanej grupie było 159 dziewcząt i 67 chłopców.

\section{WYNIKI}

Pierwszym etapem analizy było sprawdzenie, jakie style wychowania matki i ojca dominują w badanej grupie. Obliczono w tym celu średnie dla każdego stylu (tabela 3). Według opinii badanych dzieci największe nasilenie ma styl autorytatywny prezentowany przez ich rodziców. Różnica w porównaniu ze stylem następnym w kolejności jest istotna statystycznie (test t-Studenta dla prób zależnych: dla matek $t=9.7 ; p<.0001$; dla ojców $t=3.8 ; p<.0002$ ). Istotnie rzadziej występuje styl autorytarny i permisywny (między nimi brak jest różnic istotnych statystycznie).

W kolejnym kroku sprawdzono, jakie typy informacji zwrotnych zdaniem respondentów najczęściej prezentują ich rodzice. W wypadku zachowań pozytywnych osoby badane najczęś- ciej spotykają się, zarówno ze strony matek, jak i ojców, z aprobującą informacją o charakterze ogólnym (tabela 4).

Najbardziej efektywne w komunikacji informacje szczegółowe są drugie w kolejności. Pozostałe rodzaje informacji zwrotnych pozytywnych (generalizacja i etykieta) pojawiają się wyraźnie rzadziej. Różnice między kolejnymi średnimi wynikami, odnoszącymi się do określonych rodzajów informacji zwrotnych, są istotne statystycznie (test t-Studenta dla prób zależnych: dla matek $p<.0001$; dla ojców $p<.01)^{4}$. Należy zauważyć także, że wszystkie rodzaje informacji zwrotnych pozytywnych istotnie częściej są formułowane przez matki niż przez ojców (test t-Studenta dla prób zależnych; wszystkie różnice istotne na poziomie $p<.0001)$. Zdaniem respondentów natomiast ojcowie częściej niż matki nie reagują na pozytywne zachowania swoich dzieci (test t-Studenta dla prób zależnych: $\mathrm{t}=4.31 ; p<.0001)$.

W odniesieniu do zachowań negatywnych w opinii dzieci oboje rodzice najczęściej reagują konstruktywną krytyką, która w komuni-

Tabela 3. Nasilenie stylów wychowania

\begin{tabular}{|l|c|c|}
\hline & $\begin{array}{c}\text { Matka } \\
\mathbf{N = 2 2 5}\end{array}$ & $\begin{array}{c}\text { Ojciec } \\
\mathbf{N = 2 0 8}\end{array}$ \\
\hline Styl autorytatywny & 35.5 & 32.6 \\
\hline Styl autorytarny & 29.2 & 29.6 \\
\hline Styl permisywny & 29.1 & 28.7 \\
\hline
\end{tabular}

Tabela 4. Częstość stosowania różnych informacji zwrotnych w odniesieniu do pozytywnych zachowań (min. 6, max. 30)

\begin{tabular}{|l|c|c|}
\hline & Matka & Ojciec \\
\hline Informacja pozytywna ogólna & 20.16 & 18.10 \\
\hline Informacja pozytywna szczególowa & 17.13 & 15.00 \\
\hline Etykieta pozytywna & 13.92 & 12.90 \\
\hline Generalizacja pozytywna & 15.05 & 13.51 \\
\hline Brak reakcji & 11.40 & 12.88 \\
\hline
\end{tabular}


kacji jest uważana za najskuteczniejszą formę informacji zwrotnej korygującej zachowanie (tabela 5). Przy czym matki stosują ją częściej niż ojcowie (test t-Studenta dla prób zależnych $\mathrm{t}=9.46 ; p<.0001$ ). Dalej w kolejności (według wartości średnich) znajduje się negatywna etykieta, a najrzadziej pojawia się destrukcyjna krytyka (u matek) oraz generalizacja (u ojców). Podobnie jak w wypadku zachowań pozytywnych, ojcowie częściej niż matki nie reagują na zachowania negatywne (test t-Studenta dla prób zależnych $\mathrm{t}=5.18 ; p<.0001)$.

Głównym celem niniejszych badań było poszukiwanie związków między stylem wychowania matki i ojca a stosowanymi przez nich informacjami zwrotnymi. Współczynniki korelacji r-Pearsona prezentuje tabela 6 .

Najwięcej istotnych zależności występuje w odniesieniu do stylu autorytatywnego prezentowanego przez matkę i ojca. Zgodnie z hipotezą pierwszą, im bardziej nasilony ten styl, tym częściej respondenci doświadczają różnych pozytywnych informacji zwrotnych oraz konstruktywnej krytyki. Dodatkowo można zauważyć, że im bardziej autorytatywni są rodzice, tym rzadziej zarówno stosują nieefektywne informacje negatywne, jak i powstrzymują się od komentowania zachowań pozytywnych i negatywnych. Styl ten wiąże się zatem z najbardziej efektywnymi i pożądanymi w komunikacji informacjami zwrotnymi ze strony i matek, i ojców.

Kilka istotnych zależności wystąpiło również w odniesieniu do stylu autorytarnego. Zgodnie z przewidywaniami zawartymi w hipotezie drugiej, im bardziej jest on nasilony (zwłaszcza u matek), tym rzadziej pojawiają się pozytywne komunikaty (ogólne, szczegółowe, etykiety), a tym częściej (u obojga rodziców) występują komentarze w postaci negatywnych etykiet, generalizacji i krytyki o charakterze destrukcyjnym. Im rodzice są bardziej autorytarni, tym częściej powstrzymują się od reakcji na zachowania pozytywne. Co ciekawe, nie pojawiły się żadne istotne zależności między tym stylem a konstruktywną krytyką.

Najmniej istotnych zależności wystąpiło w wypadku stylu permisywnego. Uzyskano rezultat potwierdzający hipotezę trzecią, ale tylko w odniesieniu do matek: im bardziej są one permisywne, tym częściej nie reagują na zachowania negatywne (współczynnik korelacji okazuje się istotny, ale niski). W przypadku ojców pojawiły się trzy istotne zależności, których nie przewidziano w hipotezach): im większa permisywność, tym rzadziej formułują oni destrukcyjną krytykę i negatywne generalizacje oraz tym częściej komunikują się przez pozytywne etykiety (ta ostatnia korelacja jest niska).

\section{DYSKUSJA}

Przedstawione rezultaty badania poszerzają wiedzę dotyczącą stylów wychowania w rodzinie w aspekcie komunikacji. Ponieważ informacje zwrotne są ważnym narzędziem wpływania na zachowanie, interesujące jest to, czy rodzice odpowiednio wykorzystują te możliwości. Badania potwierdzają, że styl autorytatyw-

Tabela 5. Częstość stosowania różnych informacji zwrotnych w odniesieniu do negatywnych zachowań (min. 6, max. 30)

\begin{tabular}{|l|c|c|}
\hline & Matka & Ojciec \\
\hline Konstruktywna krytyka & 18.08 & 15.02 \\
\hline Etykieta negatywna & 12.88 & 12.15 \\
\hline Generalizacja negatywna & 10.48 & 9.99 \\
\hline Destrukcyjna krytyka & 10.02 & 10.15 \\
\hline Brak reakcji & 10.52 & 11.81 \\
\hline
\end{tabular}


Tabela 6. Związek stylu wychowania z rodzajem informacji zwrotnych (współczynniki korelacji r-Pearsona)

\begin{tabular}{|c|c|c|c|c|c|c|}
\hline & \multicolumn{2}{|c|}{ Styl autorytatywny } & \multicolumn{2}{|c|}{ Styl autorytarny } & \multicolumn{2}{|c|}{ Styl permisywny } \\
\hline & Matka & Ojciec & Matka & Ojciec & Matka & Ojciec \\
\hline Informacja pozytywna ogólna & $.56^{* *}$ & $.54 * *$ & $-.15^{*}$ & -.12 & .02 & .12 \\
\hline $\begin{array}{l}\text { Informacja pozytywna szcze- } \\
\text { gółowa }\end{array}$ & $.58 * *$ & $.52 * *$ & $-.18^{*}$ & -.11 & .06 & .06 \\
\hline Generalizacja pozytywna & $.43^{* *}$ & $.39 * *$ & $-.15^{*}$ & -.13 & .00 & .07 \\
\hline Etykieta pozytywna & $.39 * *$ & $.40 * *$ & -.11 & -.11 & .07 & $.14^{*}$ \\
\hline $\begin{array}{l}\text { Zachowania pozytywne - } \\
\text { brak reakcji }\end{array}$ & $-.52 * *$ & $-.43 * *$ & $.17^{*}$ & $.19^{*}$ & -.06 & -.10 \\
\hline Konstruktywna krytyka & $.55^{* *}$ & $.49 * *$ & -.03 & .01 & -.04 & -.02 \\
\hline Etykieta negatywna & $-.21 * *$ & $-.17 * *$ & $.24 * *$ & $.26 * *$ & .06 & -.12 \\
\hline Generalizacja negatywna & $-.32 * *$ & $-.26 * *$ & $.33 * *$ & $.37 * *$ & -.09 & $-.22 *$ \\
\hline Destrukcyjna krytyka & $-.27 * *$ & $-.27 * *$ & $.30 * *$ & $.28 * *$ & -.09 & $-.15^{*}$ \\
\hline $\begin{array}{l}\text { Zachowania negatywne - } \\
\text { brak reakcji }\end{array}$ & $-.30 * *$ & $-.32 * *$ & -.05 & .03 & $.18^{*}$ & .09 \\
\hline
\end{tabular}

$* p<.05, * * p<.001$

ny - uważany za najlepszy w naszej kulturze wzorzec relacji między rodzicem a dzieckiem - rzeczywiście charakteryzuje się najbardziej efektywną komunikacją, obfitującą w pozytywne komentarze różnego typu. Istotne jest jednak to, że styl ten nie wiąże się jedynie z dostrzeganiem pozytywów i ich wzmacnianiem. W sytuacjach, gdy dziecko nie zachowuje się właściwie, rodzice nie powstrzymują się od reakcji, ale formułują konstruktywną krytykę, umożliwiając w ten sposób korektę zachowania i przyczyniając się do rozwoju. Im bardziej rodzice prezentują ten styl, tym częściej ograniczają negatywne komunikaty o charakterze destrukcyjnym. Taki sposób komunikacji wydaje się najbardziej efektywny i z pewnością podtrzymuje dobrą relację między rodzicami a dziećmi. Z wielu badań wynika, że osoby wychowywane według autorytatywnego stylu lepiej funkcjonują w różnych sferach, m.in: są bardziej dojrzałe społecznie, odpowiedzialne i osiągają sukcesy edukacyjne (Baumrind, 1971), mają wyższą samoocenę (Milevsky, Schlechter, Netter, 2007; Cierpka, Wierzbicka, 2013), bardziej pozytywnie oceniają relacje z rodzicami (McGillicuddy-De Lisi, De Lisi, 2007), rzadziej doświadczają problemów natury psychicznej, takich jak depresja (Milevsky $i$ in., 2007) oraz uzależnienie od substancji psychoaktywnych (Baumrind, 1991; Lamborn, Mounts, Steinberg, Dornbusch, 1991; Adalbjarnardottir, Hafsteinsson, 2001). Można zatem przyjąć, że stosowanie takiego wzorca informacji zwrotnych, jaki ujawnił się w niniejszym badaniu, również się przyczynia do osiągania tych pozytywnych efektów.

$\mathrm{Na}$ przeciwległym krańcu oddziaływań wychowawczych znajduje się styl autorytarny, w którym komunikacja (w zakresie formułowania oczekiwań) ma najbardziej jednostronny 
charakter. Informacje zwrotne formułowane przez rodziców prezentujących ten styl mają również swój charakterystyczny rys. W przypadku matek, im więcej jest $\mathrm{w}$ wychowaniu cech autorytarnych, tym częściej spotyka się brak reakcji na zachowania pozytywne, tym rzadziej pojawiają się informacje pozytywne oraz tym częściej prezentowane są nieefektywne komunikaty negatywne, wyrażające dezaprobatę, z której trudno wyciągnąc konstruktywne wnioski. Im bardziej nasilony jest styl autorytarny ojca, tym częściej nie reaguje on na pozytywne zachowania oraz tym częściej mówi nieefektywne komunikaty negatywne. Warto zauważyć, że w wypadku tego stylu nie ujawniły się istotne zależności w odniesieniu do konstruktywnej krytyki, która jest przecież pożądaną formą modyfikacji zachowania. Chociaż zatem rodzicie autorytarni są najbardziej nastawieni na kontrolowanie zachowania swoich dzieci i wywoływanie pożądanych zmian, w rezultacie swoich zabiegów komunikacyjnych okazują się zdecydowanie skazani na fiasko tych usiłowań. Ponadto nieefektywne, a czasem wręcz destrukcyjne informacje zwrotne z pewnością wpływają niekorzystnie na ocenę relacji przez dzieci i mają dalsze negatywne skutki dla ich funkcjonowania (por. np. McGillicuddy-De Lisi, De Lisi, 2007).

Najmniej zależności ujawniło się w odniesieniu do stylu permisywnego. Nie oznacza to, że rodzice, u których styl ten jest nasilony, nie przekazują swoim dzieciom różnych informacji zwrotnych. Można jedynie stwierdzić, że informacje te nie mają $\mathrm{w}$ tym wypadku jakiegoś wspólnego wzorca. Pewnym wyjaśnieniem tych rezultatów może być to, że skala permisywności zawarta w Kwestionariuszu Autorytetu Rodzicielskiego (zarówno w wersji oryginalnej, jak i polskiej) jest najmniej spójna, stąd też uzyskane wyniki mogą odzwierciedlać tę psychometryczną niedoskonałość.

Jednakże niektórzy badacze zauważają, że sama kategoria permisywności nie jest jednorodna. Eleanor Maccoby i John Martin (1983) zaproponowali, aby rozpatrywać styl permisywny - ale też dwa pozostałe - $\mathrm{z}$ uwzględnieniem dwóch ortogonalnych wymiarów:

1. akceptacji i zaangażowania rodziców;

2. zakresu wymagań i kontroli.
Każdy z tych wymiarów może być nasilony w różnym stopniu. Wysokie nasilenie akceptacji i wymagań jest charakterystyczne dla stylu autorytatywnego. Niskie nasilenie akceptacji przy wysokiej kontroli i dużych wymaganiach odpowiada stylowi autorytarnemu. W stylu permisywnym oczywistymi cechami charakterystycznymi okazują się niska kontrola i małe wymagania. Jednakże stosunek emocjonalny do dziecka wydaje się bardziej złożony (co jest szerszym spojrzeniem w stosunku do oryginalnej koncepcji D. Baumrind). Jeśli akceptacja jest wysoka, to styl taki można nazywać pobłażliwym, przyzwalającym (induglent). Jeśli niska kontrola wiąże się $\mathrm{z}$ niskim poziomem zaangażowania i emocjonalnym chłodem, to styl taki nazywany jest niezaangażowanym lub niedbałym (neglectful). Susie D. Lamborn i współpracownicy (1991) twierdzą, że te dwa sposoby wychowywania dzieci wynikają z różnych „orientacji ideologicznych” rodziców. Styl pobłażliwy jest oparty na zaufaniu, demokracji i wyrozumiałości. Styl niedbały natomiast wynika $\mathrm{z}$ braku zaangażowania i niskiego poczucia odpowiedzialności za wychowanie dziecka. Badania (Lamborn i in., 1991) potwierdziły, że osoby, które wychowywane były przez rodziców pobłażliwych w porównaniu z zaniedbującymi inaczej funkcjonowały w okresie adolescencji. Ci pierwsi mieli silne poczcie zaufania do siebie (self-confidence), częściej jednak doświadczali problemów szkolnych i uzależnień. Adolescenci, których rodzice byli opisywani jako zaniedbujący, mieli natomiast najniższe wskaźniki kompetencji społecznych oraz najczęściej doświadczali różnych dysfunkcji psychicznych i behawioralnych. Ta złożoność obrazu rodziców, którzy zaliczani są według D. Baumrind do kategorii permisywnych, wydaje się też wiązać z odmiennymi wzorcami komunikacji. Być może brak reakcji na zachowania pozytywne i negatywne jest charakterystyczny dla rodziców zaniedbujących, a pobłażliwi opiekunowie formułują komunikaty pozytywne o charakterze ogólnym, ale powstrzymują się od konstruktywnej krytyki. Hipotezy te wymagają jednak dalszej weryfikacji z wykorzystaniem innego narzędzia pozwalającego na wyróżnienie dwóch podtypów stylu permisywnego. 


\section{PODSUMOWANIE}

Badanie wzorców komunikacyjnych obejmujących informacje zwrotne w relacjach między rodzicami a dziećmi uzupełnia wiedzę dotyczącą stylów wychowania. Styl autorytatywny wiąże się z bardziej efektywną komunikacją, w której dominują informacje zwrotne pozytywne, a także konstruktywna krytyka. Styl autorytarny charakteryzuje się zdecydowanie nieefektywną komunikacją. W odniesieniu do stylu permisywnego informacje zwrotne udzielane przez rodziców nie mają wspólnego wzorca. W świetle uzyskanych wyników komunikacja matki z dzieckiem charakteryzuje się większą częstością informacji zwrotnych niż komunikacja ojców z dzieckiem. Ponieważ badanie prowadzono $\mathrm{z}$ perspektywy adolescentów, cennym uzupełnieniem obrazu byłoby uzyskanie analogicznych danych od rodziców. Biorąc pod uwagę zmiany procesów komunikacyjnych $\mathrm{w}$ rodzinie, wynikające $\mathrm{z}$ rozwojowych zmian partnerów interakcji, w dalszych badaniach interesujące byłoby również analizowanie informacji zwrotnych w modelu longitudinalnym. Ważne z rozwojowej perspektywy byłoby także zbadanie skutków otrzymywania różnych typów informacji zwrotnych dla istotnych aspektów funkcjonowania odbiorcy, np. kształtowania autonomii, samooceny, samoskuteczności.

\section{PRZYPISY}

${ }^{1}$ Prace nad polską wersją kwestionariusza PAQ rozpoczęli Anna Cierpka, Anna Oleszkowicz i Janusz Trempała (praca nieopublikowana; materiały uzyskane bezpośrednio od autorów). Po przetłumaczeniu pozycji kwestionariusza prowadzone są obecnie badania mające na celu określenie parametrów psychometrycznych.

${ }^{2}$ Pojęcie konstruktywnej krytyki oraz zasad jej sformułowania jest w komunikacji interpersonalnej ujmowane w zdecydowanie bardziej rozbudowany sposób niż w prezentowanej tu metodzie (np. Bee, Bee, 2000). Podkreśla się m.in., że krytyka powinna być połączona z informacją o mocnych stronach, że powinna mówić o faktach (co jest nieprawidłowe), ustosunkowaniu do nich oraz oczekiwaniach na przyszłość (tzw. model FUO; Król-Fijewska, Fijewski, 2000). Przedstawienie w tym miejscu szczegółowych zasad przekazywania konstruktywnej krytyki wymagałoby znacznie szerszego opracowania. Jednakże najważniejsze jest to, że konstruktywna krytyka powinna precyzyjnie ujmować, na czym polega nieprawidłowość zachowania oraz co i jak należy poprawić. $Z$ uwagi na kwestionariuszową formę prezentowanej tu metody (wymagającą ujednolicenia strony formalnej), starano się w niej zawrzeć właśnie te dwa główne elementy: co jest nieprawidłowe oraz jak to można zmienić.

${ }^{3}$ Badania prowadziły studentki: Malwina Boryczka, Małgorzata Kępa, Paulina Kotuła, Patrycja Prochacka, Marta Rawa, którym w tym miejscu dziękuję za współpracę.

${ }^{4} \mathrm{~W}$ przypadku ojców jedynie różnica między częstością pozytywnych etykiet a brakiem reakcji jest nieistotna.

\section{BIBLIOGRAFIA}

Adalbjarnardottir S., Hafsteinsson L.G. (2001), Adolescents' Perceived Parenting Styles and their Substance Use: Concurrent and Longitudinal Analyses. Journal of Research on Adolescence, 11, 4, 401-423.

Barbour A. (2003), Interpersonal Feedback: Origins and Applications, http://www.eric.ed.gov/contentdelivery/ servlet/ERICServlet?accno=ED474585 (dostęp: 1.07.2016).

Baumrind D. (1966), Effects of Authoritative Parental Control on Child Behavior. Child Development, 37, 4, 887-907.

Baumrind D. (1967), Child Care Practices Anteceding Three Patterns of Preschool Behavior. Genetic Psychology Monographs, 75, 43-88.

Baumrind D. (1971), Current Patterns of Parental Authority. Developmental Psychology Monographs, 4 (1), $1-103$. 
Baumrind D. (1991), The Influence of Parenting Style on Adolescent Competence and Substance Use. The Journal of Early Adolescence, 11, 56-95.

Bee R., Bee F. (2000), Feedback. Warszawa: Petit.

Buri J.R. (1991), Parental Authority Questionnaire. Journal of Personality Assessment, 57 (1), 110-119.

Brzezińska A. (2000), Społeczna psychologia rozwoju. Warszawa: Wydawnictwo Naukowe Scholar.

Cierpka A., Wierzbicka J. (2013), Samoocena młodych dorosłych a style wychowania w rodzinie pochodzenia. Psychologia Wychowawcza, 4, 80-92.

Gunderson E.A., Gripshover S.J., Romero C., Dweck C.S., Goldin-Meadow S., Levine S.C. (2013), Parent Praise to 1- to 3-Year-Olds Predicts Children's Motivational Frameworks 5 Years Later. Child Development, 84, 5, 1526-1541.

Harwas-Napierała B. (2006), Komunikacja interpersonalna w rodzinie. Poznań: Wydawnictwo Naukowe UAM.

Hattie J., Timperly H. (2007), The Power of Feedback. Review of Educational Research, 1, 77, 81-112.

Kamins M.L., Dweck C.S. (1999), Person Versus Process Praise and Criticism: Implications for Contingent Self-Worth and Coping. Developmental Psychology, 35, 3, 835-847.

Król-Fijewska M., Fijewski P. (2000), Asertywność menedżera. Warszawa: Polskie Wydawnictwo Ekonomiczne.

Lamborn S.D., Mounts N.S., Steinberg L., Dornbusch S.M. (1991), Patterns of Competence and Adjustment Among Adolescents from Authoritative, Authoritarian, Indulgent, and Neglectful Families. Child Development, 62, 5, 1049-1065.

Liberska H. (2011), Teorie rozwoju psychicznego. W: J. Trempała (red.), Psychologia rozwoju człowieka, 71-125. Warszawa: Wydawnictwo Naukowe PWN.

Maccoby E.E, Martin J.A. (1983), Socialization in the Context of Family: Parent-Child Interaction. W: P.H. Munsen (ed. tomu), E.M. Hetherington (ed. serii), Handbook of Child Psychology, t. 4, 1-101. New York: Wiley.

McGillicuddy-De Lisi A.V., De Lisi R. (2007), Perceptions of Family Relations when Mothers and Fathers are Depicted with Different Parenting Styles. Journal of Genetic Psychology, 168, 4, 425-442.

Milevsky A., Schlechter M., Netter S. (2007), Maternal and Paternal Parenting Styles in Adolescents: Associations with Self-Esteem, Depression and Life-Satisfaction. Journal of Child and Family Studies, 16, 1, 39-47.

Rawa M. (2012), Rodzaje przekazywanych młodzieży informacji zwrotnych w sytuacjach zadaniowych $i$ wychowawczych. Uniwersytet Wrocławski, Instytut Psychologii, nieopublikowana praca magisterska.

Stone D., Heen S. (2014), Thanks for the Feedback: The Science and Art of Receiving Feedback Well. London: Portfolio Penguin.

Tyszkowa M., Przetacznik-Gierowska M. (1996), Wybrane koncepcje i teorie rozwoju psychicznego człowieka. W: M. Przetacznik-Gierowska, M. Tyszkowa (red.), Psychologia rozwoju człowieka, 189-221. Warszawa: Wydawnictwo Naukowe PWN.

Watzlawick P., Beavin J.H., Jackson D.D. (1967), Pragmatics of Human Communication. New York: W.W. Norton. 